\title{
Civil Society and Its Institutional Context in CEE
}

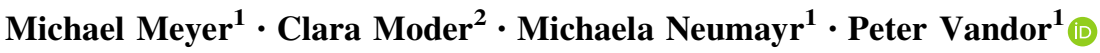

Published online: 11 March 2019

(C) The Author(s) 2019

\begin{abstract}
Although civil societies in Central and Eastern Europe are often portrayed as similar, united by a shared communist past, they have developed along increasingly divergent trajectories over the past three decades. This article investigates the current state of civil society in the region and the role the institutional context plays in it. Drawing on historical institutionalism and the process of European integration, we classify the 14 countries under investigation into three distinct groups and analyze data from a survey of more than 350 local civil society experts. We find that, together with domestic governments, international donors and the EU are perceived as the most influential institutional actors for civil society organizations. Their respective influences, however, depend largely on a country's stage in the EU accession process. Overall, the study provides a differentiated mapping of civil society in this region and a better understanding of how the institutional context relates to a country's civil society.
\end{abstract}

Keywords Civil society - Central and Eastern Europe (CEE) - Historical institutionalism - Institutional context . European integration

Peter Vandor

Peter.Vandor@wu.ac.at

Michael Meyer

Michael.Meyer@wu.ac.at

Clara Moder

clara.moder@univie.ac.at

Michaela Neumayr

Michaela.Neumayr@wu.ac.at

1 Wirtschaftsuniversität Wien, Vienna, Austria

2 University of Vienna, Vienna, Austria

\section{Introduction}

Over the last three decades, civil society in Central and Eastern Europe (CEE) has developed with unprecedented dynamism. While it has experienced strong growth throughout the region, with the number of civil society organizations (CSOs) increasing sharply, the trajectories and roles of the different civil societies (CS) have varied significantly since the collapse of communist regimes (Ekiert and Kubik 2014; Vandor et al. 2017). ${ }^{1}$ In Hungary, for instance, independent CSOs face discrimination and persecution by the government (Kuti 2017), whereas in some countries they have become important partners of the public sector by advocating for social services (Domaradzka 2018; Jezierska and Polanska 2018; Piotrowski 2015) or delivering them (Navrátil and Pecjal 2017). In others again, parts of CS are strongly supported by international actors, yet under suspicion of being detached from citizens (Spahić-Šiljak 2017).

Despite the large number of studies investigating the state of CS in individual CEE countries, there has been little comparative research offering a contemporary perspective on the role of CS across the region (Salamon et al. 2004; Toepler and Salamon 2003), and even less work that tries to understand the divergent developments. Indeed, we still find rather homogenous depictions of CS across CEE

\footnotetext{
${ }^{1}$ While the concept of CSO includes any private, self-governing, and institutionalized organization that does not distribute profit to its owners and involves some form of voluntary participation (Salamon and Anheier 1998, p. 216), the concept of CS is much broader. It is defined as the arena outside the state, the market and the family where people associate to advance common interest (Heinrich 2007). In this arena, collective action in CSOs and also through other, less institutionalized forms of engagement take place (e.g., demonstrations, social movements, boycotts) (Heinrich 2005, p. 213).
} 
in existing scholarly work, which emphasizes shared past experiences, specifically the legacy of totalitarian communist regimes and the unprecedented political and economic transformations experienced by societies in the region (Howard 2002, 2003; Kendall et al. 2000; Lauth 2017; Rikmann and Keedus 2013; Toepler and Salamon 2003). In contrast, the influence of more recent historical events and of the institutional context in individual countries has received hardly any attention (for an exception see Aksartova 2009), and comparative research on the role of institutional contexts is completely lacking.

Our study seeks to fill this gap by exploring the influence of institutional context on CSOs in $14 \mathrm{CEE}$ countries, ${ }^{2}$ taking account of their different paths toward Euoprean Union (EU) membership since 1989. Specifically, we try to answer two questions. First, how do local civil society experts perceive the influence of the institutional context and its actors (e.g., central government, foreign donor institutions, the European Union) in shaping civil society? And, second, how do these expert assessments differ between groups of countries that have reached similar stages in the process of moving toward EU membership and beyond?

So far, research on CS's institutional context has typically built on the social origins theory (SOT) (cf. Salamon and Anheier 1998). Though this approach has been useful for Western societies, it is less applicable to other countries (Kabalo 2013). Therefore, our study takes a different one. Drawing on historical institutionalism, we reflect on the process of EU accession as a critical juncture for each of the 14 countries (Vandor et al. 2017). Additionally, we explore data from a survey conducted in these states, including the assessments of more than 350 experts regarding the influence on $\mathrm{CS}$ of the institutional context and key actors within it, and of how that context relates to recent developments in CS in their countries.

Thus, we aim to go beyond existing research in four ways. First, we seek to offer a contemporary perspective on $\mathrm{CS}$ in CEE. Second, following Rikmann and Keedus (2013), we peek "behind the façade of the relative homogeneity" of civil society in CEE and divide our 14 countries into three groups on the basis of their paths toward EU membership. Third, our study is the first to represent a comprehensive analysis of the institutional context of CS in CEE. Finally, we aim to contribute to third sector research by expanding on social origins theory and acknowledging the important role of foreign institutional forces for CSOs.

We begin by discussing historical institutionalism and social origins theory, arguing that both the role of foreign actors and the insights of scholars of European integration

\footnotetext{
${ }^{2}$ All those that did not form part of the Soviet Union prior to 1989. The Baltic States, Moldova, Ukraine and Belarus are therefore not included.
}

should be taken more explicitly into account. We then cluster the 14 countries into three groups according to their rate of progress toward EU membership. Then, after describing our survey data and methodology, we analyze the perceived influence of various institutional actors in each of the three country groups and discuss how these actors relate to the role and activities of CSOs. We conclude with a discussion of our main findings, their implications for research and their limitations.

\section{Theoretical Framework and Research Review}

Scholars have long been analyzing institutions and their impact on societies (Kendall et al. 2000; Kitschelt 1992; Skocpol and Somers 1980). This approach, institutionalism, has proven to be powerful in explaining complex phenomena (Boli and Thomas 1997; Drori et al. 2006; Thelen 1999), including global variations in the role of civil society. In accordance with the literature (March and Olsen 1984; Peters 2011), we understand institutions as societal structures that are based on both formal rules (e.g., legal frameworks) and informal ones (e.g., those deriving from a set of shared norms). Both types evolve slowly over long periods of time and guide and constrain the behavior of individual and organizational actors alike. Analyzing institutions thus implies identifying how they construct agency and which forces shape them (Meyer et al. 1987; Ruef and Scott 1998; Scharpf 1997; Scott 2000; Scott and Meyer 1994; Tolbert 1985). As regards societies' institutional context, institutional forces are exerted mainly by collective actors, which include formally organized actors typically structured by (top-down) rules (Scharpf 1997), e.g., governments, foundations or churches.

Historical institutionalism, which focuses on the genesis and history of institutions and their consequences in the present, suggests that political and societal outcomes are conditioned both by path dependency and by critical junctures in time. Empirically, historical institutionalists focus on the qualitative analysis of case studies of nations and regions in order to gain insights into the evolution of societal institutions and outcomes (Kerlin 2013). Since institutional change is caused not only by transitions from one system to another, but also by the interaction, re-arrangement and re-combination of different institutions (Schmidt 2010; Scott 2000; Smets et al. 2012; Thelen 1999), historical institutionalism provides a useful theoretical perspective in explaining the emergence and persistence of institutions that facilitate collective action (Tilly 1984).

Historical institutionalism also provides scholars with insights about transition and post-communist patterns of democratization, societal development and civil society activity (Merkel 2010). Civil society activity has been 
related to two different types of historical legacy, the first being that of communism. On this view, the comparatively low levels of participation in CSOs in post-communist countries are explained by such factors as forced membership in organizations and the resultant highly politicized public sphere. This has led to the notion that post-communist civil societies are relatively "weak" (Howard 2002; Pop-Eleches and Tucker 2013).

Secondly, through their social orginis theory (which builds on the work of Moore, 1966, and Esping-Andersen 1990), Salamon and Anheier (1998), explain third sector patterns in different countries by past political and economic struggles. They assume that, like the emergence of democracy or a welfare state, the third sector's role in a particular country has been determined by the balance of power between the urban middle class, a rural peasantry, landed elites and the state (Salamon and Anheier 1998, p. 227; Smith and Grønbjerg 2006). To describe that role, they locate countries on each of two dimensions: level of government spending and third sector size (in employment terms). The resulting grid enables countries to be categorized into one of four so-called nonprofit regimes: statist, liberal, social democratic and corporatist. While the framework gives most weight to the state, it nevertheless reflects "a particular constellation of social forces" (Salamon et al. 2000). SOT has been criticized for various reasons (e.g., Ragin 1998; Steinberg and Young 1998): the aggregate conception of the third sector, which makes it impossible to account for its heterogeneity; the limited attention to nonlinear relationships; and the over-emphasis on social service provision. Yet its achievement in rendering third sectors both visible and comparable is widely acknowledged, and it has been widely applied in order to map, analyze and categorize third sectors in different countries (Salamon et al. 2004; Toepler and Salamon 2003).

However, while SOT remains a helpful framework for analyzing and clustering "Western" third sectors, it has been less helpful for post-transition countries. As Salamon et al. themselves note, "the Eastern European countries in our sample represent an interesting mix of the statist and social-democratic tendencies" (2000, p. 20). At the same time, they acknowledge that patterns of government spending on social policy and on CSOs in formerly communist countries are hardly comparable to Western ones. Some critics have gone further; Ekiert and Foa (2011), for example, challenge the very notion of "post-communist civil society." Other research on transition countries has pointed to a need to include factors beyond state-nonprofit relations in explanatory models. In her analysis of Israel and Palestine, Kabalo (2013) found that a systemic change from foreign to domestic influence has altered relations between the state and the nonprofit sector and concluded that diaspora movements are important influences on civil society. $^{3}$

In CEE, it is clear that CSs have been heavily influenced by foreign institutions (Ottaway and Carothers 2000), especially by the European Union. Scholars of European integration have analyzed the EU's role as a foreign actor, building domestic institutions and funding CSOs in order to nurture CS and so promote democracy (Beichelt et al. 2014). Most of them focus on formal institutions and government behavior, establishing the notion of EU conditionality-the idea that a country is more likely to align its legislation with EU directives if it has a realistic prospect of accession (Börzel and Risse 2005; Schimmelfennig and Sedelmeier 2004) — and pointing to a decline in EU influence after accession (Ganev 2013; Sedelmeier 2017). Those investigating CS emphasize CSOs' strategies to exploit political opportunity structures and mobilize resources in the light of possible EU membership (Buzogány 2011; Wunsch 2016), their success in holding governments to account (Dimitrova and Buzogány 2014) or their involvement in policy- and decision-making (Börzel and Buzogány 2010). Fewer studies investigate the impact of the EU and other foreign forces on CS, and those that do find that this influence has been highly contradictory (Fagan 2006; Kutter and Trappmann 2010) and difficult to gauge (Shapovalova and Youngs 2014). Whereas the EU has brought benefits for larger CSOs, it may actually have hindered the emergence of grassroots movements or the establishment of sustainable income sources (Börzel 2010).

Here, it is important to note that the EU has not always been active in CS funding. Prior to the Eastern enlargement of 2004-2007, it focused on technical assistance and legislative advice, leaving CSO funding largely to foundations and donor institutions such as the CEE Trust, Mott Foundation or the United States Agency for International Development (USAID) (Fagan 2006). Only following establishment of the Eastern Partnership Program did CS become a more explicit element of both European neighborhood policy and membership negotiations (Shapovalova and Youngs 2014). Nevertheless, potential and actual European membership and EU-led programs have had an enormous impact on the institutional context in which CSOs operate, especially on legislation and state-civil society relations (Fagan and Wunsch 2018; Kutter and Trappmann 2010). Thus, these relations depend not only on government spending (cf. Kamerāde et al. 2016) and domestic institutions, but also on other factors neglected by SOT.

\footnotetext{
3 This criticism mirrors the earlier debate on Moore's (1966) work on social origins of modernization in various societies. As Skocpol (1973, p. 12) notes, a "theoretical focus on exclusively intrasocietal change-producing processes" is too narrow because "no society is free from foreign influences" (1973, p. 29).
} 
In this study, we therefore deviate from social origins theory and focus on domestic and foreign institutional forces, particularly the EU. We emphasize especially how CS experts in our 14 countries perceive the degree of influence these forces exert on civil society. We assume that the EU's influence diminishes as a country has received membership. With regard to the influence of other institutional forces, we formulate no assumptions and take an explorative approach. We also seek to explore what the countries of the region have in common in terms of their recent development.

\section{Grouping Countries by Their Stage in the Process of EU Accession}

The fact that all countries in CEE share a communist past scarcely explains the diverse paths that they have taken. Indeed, it is obvious how vastly different the outcomes of the democratic transitions have been. We argue that the most significant factor in accounting for current differences in the state of CSs is the role of the European Union in setting the institutional context. We therefore classify the 14 countries under investigation into three distinct groups according to the stage they have reached in the process of EU accession.

The first group comprises the Visegrád countries (Czech Republic, Hungary, Poland, and Slovakia) and Slovenia. These five countries were in the vanguard when it came to liberalizing the economy and democratizing politics. All of them progressed rapidly toward membership during the 1990s and were part of the first EU Eastern enlargement in 2004 (Sedelmeier 2014).

The countries of the second group joined the EU some years later: Bulgaria and Romania in 2007, Croatia in 2013. In the cases of Bulgaria and Romania, EU accession was postponed from 2004 as they continued to struggle against persistent corruption and in implementing the reforms necessary to meet the Copenhagen criteria (Noutcheva and Bechev 2008). This experience led the EU to impose stricter accession criteria on Croatia. Along with the economic crisis of 2008 and Slovenia's lengthy blockade of negotiations, this meant that the country only became the 28th EU member state in July 2013 (TitanskiHooper 2015).

Finally, the remaining six countries have not yet joined European Union and have differing prospects of future accession. Albania, Republic of North Macedonia, Montenegro and Serbia have already obtained candidate status (albeit negotiations have started only with Serbia and Montenegro), whereas Bosnia and Herzegovina and Kosovo are currently listed as potential candidates. The former's application for candidate status is currently under investigation, while Kosovo's situation is complicated by the fact that some existing member states do not acknowledge its independence from Serbia, which it declared in 2008 (European Commission 2016).

Apart from having progressed similarly toward EU accession, the countries within each of the three groups are also similar in economic terms, as can be seen from Table 1, which shows key indicators for all the countries included in our study. For example, GDP per capita expressed in Purchasing Power Standards is considerably higher in Group 1 countries than in those making up Group 2 and more than double that of countries in Group 3. Similarly, the country groups differ with respect to the share of employees active in CSOs (averages per group: $1.8 \%, 1.2 \%$ and $0.8 \%$ ), to the number of CSOs per 1000 citizens (averages per group: 7.4, 5.3 and 2.7), and to the level of informal forms of civic engagement.

\section{Data and Methodology}

Our explorative study builds on two types of sources. First, it is based on the literature and policy reports about CS in the region, including country-specific (e.g., Parau 2009) and conceptual work (Börzel 2010; Ekiert and Kubik 2014; Kutter and Trappmann 2010), as well as on recent comparative studies on CS in CEE (Rikmann and Keedus 2013; Vandor et al. 2017). Second, our analysis draws on data we collected using a survey of CS experts in our 14 countries. The countries had been selected to include all former independent Socialist countries or their successor states within the region. The survey was designed as an expert survey (Bogner et al. 2009; Meuser and Nagel 2009). This was deemed an appropriate approach given the sensitivity of the questions, as well as the difficulty of gaining access to other comparative data sources (see Ray 1999). In expert surveys, data are gathered from respondents with practical insider knowledge, who serve as "crystallization points" and surrogates for the knowledge of a wider circle of players (Bogner et al. 2009). Findings are thus not representative of the general population but of a subset of individuals knowledgeable in a specific fieldin our case, CS in their respective countries (Bogner and Menz 2009).

The main criterion according to which the local experts were selected for interview was professional experience in CS practice or research, this being the type of expertise most relevant for providing insight into the research question (Bogner and Menz 2009). Respondents were identified using a snowball sampling approach (Coleman 1958), which is particularly appropriate for populations in which insider knowledge is required to identify experts and for especially sensitive topics (Biernacki and Waldorf 
Table 1 CSOs and civil society in CEE: key indicators. Sources: BCSDN 2015, European Value Survey 2008 (weighted values), Eurostat 2016a and 2016b, World Bank 2016 (reference year: 2015)

\begin{tabular}{|c|c|c|c|c|c|c|c|}
\hline & $\begin{array}{l}\text { Population } \\
\text { (millions) }\end{array}$ & $\begin{array}{l}\text { Annual } \\
\text { GDP } \\
\text { growth (\%) }\end{array}$ & $\begin{array}{l}\text { GDP per capita in PPS } \\
\text { (Index, EU28 = 100) }\end{array}$ & $\begin{array}{l}\text { CSO value } \\
\text { added as } \\
\% \text { of GDP }\end{array}$ & $\begin{array}{l}\text { Share of } \\
\text { employment } \\
\text { in CSOs (\%) }\end{array}$ & $\begin{array}{l}\text { Active } \\
\text { CSOs } \\
\text { per } 1000 \\
\text { capita }\end{array}$ & $\begin{array}{l}\text { Volunteer } \\
\text { engagement } \\
(\%)\end{array}$ \\
\hline Czech Republic & 10.50 & 4.20 & 85 & 1.77 & 2.09 & 12.13 & 26.8 \\
\hline Hungary & 9.87 & 2.94 & 68 & 1.55 & 3.70 & 6.47 & 12.2 \\
\hline Poland & 38.50 & 3.65 & 69 & 1.40 & 0.90 & 2.08 & 8.5 \\
\hline Slovakia & 5.40 & 3.60 & 77 & 0.98 & 1.45 & 9.70 & 13.5 \\
\hline Slovenia & 2.06 & 2.88 & 83 & 2.06 & 1.02 & 13.90 & 32.1 \\
\hline Group 1: Sums and Averages & 66.33 & 3.45 & 76 & 1.55 & 1.83 & 8.86 & 16.9 \\
\hline Bulgaria & 7.60 & 2.97 & 46 & $\mathrm{n} / \mathrm{a}$ & 0.60 & 1.25 & 11.9 \\
\hline Croatia & 4.30 & 1.64 & 58 & $\mathrm{n} / \mathrm{a}$ & 1.56 & 13.70 & n.a. \\
\hline Romania & 20.00 & 3.74 & 57 & 0.60 & 1.20 & 1.30 & 13.2 \\
\hline Group 2: Sums and Averages & 31.90 & 2.78 & 54 & 0.60 & 1.12 & 5.42 & 12.6 \\
\hline Albania & 2.80 & 2.56 & 30 & 0.28 & 0.72 & 0.87 & 19.7 \\
\hline Bosnia and Herzegovina & 3.80 & 3.16 & 29 & 0.60 & 0.38 & 1.71 & 8.3 \\
\hline Kosovo & 1.80 & 3.62 & $\mathrm{n} / \mathrm{a}$ & $\mathrm{n} / \mathrm{a}$ & 2.58 & 4.44 & 10.4 \\
\hline North Macedonia & 2.07 & 3.67 & 37 & 0.96 & 0.38 & 2.00 & n.a. \\
\hline Montenegro & 0.62 & 3.37 & 41 & 0.58 & 0.37 & 1.69 & 7.5 \\
\hline Serbia & 7.20 & 0.73 & 36 & 1.34 & 0.34 & 5.20 & 11.2 \\
\hline Group 3: Sums and Averages & 18.29 & 2.85 & 35 & 0.75 & 0.80 & 2.65 & 11.4 \\
\hline Total & 116.5 & 3.1 & 55 & 1.10 & 1.24 & 5.46 & 13.6 \\
\hline
\end{tabular}

1981). ${ }^{4}$ Our snowball sampling started from multiple points located in research organizations in each of the selected countries and proceeded through the networks of two foundations active in the region as funders of social, cultural and journalistic causes, as well as research. Each respondent was invited to forward the survey to further experts in the field.

The survey was conducted anonymously, online and in English between February 9 and March 16, 2016. In total, 361 experts responded to it. The number of experts per country ranged from 11 in Poland to 36 in Hungary. Both the total sample size and the sample size per country can be deemed acceptable by comparison with similar multicountry expert surveys (Ray 1999; USAID 2018). More importantly, experts reported an average of 14.5 years of professional or academic experience in civil society and $80.6 \%$ stated that they were founders or directors of a CSO (see Table 2).

The goal of the survey was to elicit experts' assessments of the role and perceived influence of institutional forces on $\mathrm{CS}$ in their respective countries. In our questionnaire, we

\footnotetext{
${ }^{4}$ Given the recent criticism of, and attacks on CS by public officials and the media in some CEE countries, we deemed the topic to be sensitive.
}

presented a list of institutional actors derived from literature (e.g., Kamerāde et al. 2016; Reljic and und Sicherheit 2004; Salamon and Anheier 1998; Taylor 2000). This list was then confirmed and amended in a pre-study focus group comprising 25 members of CSOs from the region. The final list included nine types of actors relevant for civil society: (1) domestic central (federal) government, (2) domestic regional government, (3) domestic municipal (local) government, (4) the European Union, (5) corporations, (6) media, (7) private philanthropists, (8) foreign (private and public) donor institutions (such as foundations or USAID), and (9) churches and religious institutions. For each institutional actor, respondents were asked to assess its degree of influence on CS in the country concerned (on a Likert-type scale ranging from " $1=$ no influence" to " 6 = very strong influence") and to indicate whether they considered this influence positive $(=1)$, mixed $(=0)$, or negative $(=-1)$ for $\mathrm{CS}^{5}$ To assure the quality of responses, participants were permitted to omit assessment of certain actors if felt they lacked adequate information.

\footnotetext{
5 The exact questions posed were: "How influential are the following actors of the institutional environment of civil society in your country? How positive or negative is their influence on the development of civil society in scale and scope?"
} 
Table 2 Sample characteristics by country

\begin{tabular}{llll}
\hline Country & \multicolumn{2}{l}{ Respondent characteristics } & Co-founder or director of CSO (\%) \\
\cline { 2 - 4 } & Sample size & Years of work experience (average) & 60.0 \\
\hline Albania & 25 & 14.12 & 83.3 \\
Bosnia and Herzegovina & 30 & 16.30 & 88.2 \\
Bulgaria & 17 & 14.82 & 75.6 \\
Croatia & 33 & 12.88 & 82.6 \\
Czech Republic & 23 & 12.00 & 83.3 \\
Hungary & 36 & 20.69 & 85.7 \\
Kosovo & 14 & 8.36 & 100.0 \\
Montenegro & 25 & 14.64 & 45.4 \\
Poland & 11 & 20.82 & 96.8 \\
Republic of North Macedonia & 31 & 12.94 & 78.1 \\
Romania & 32 & 11.50 & 86.6 \\
Serbia & 30 & 10.50 & 78.6 \\
Slovak Republic & 28 & 13.21 & 65.3 \\
Slovenia & 26 & 20.19 & \\
\hline
\end{tabular}

Of the 361 respondents, 283 provided at least one rating for the perceived influence of actors. All the ratings were included in our analysis.

Since 'influence' is an ambiguous concept and can be exerted on various levels and through multiple channels, its measurement is extremely challenging. However, assessing 'perceived' and 'attributed influence' has proven to be a useful approach to capturing its various forms (Baranowski and Gross 2006; Dür 2008). Checking for reliability, we computed Krippendorff's alpha values for the assessments of the degree and direction of actors' perceived influence on CS; these ranged from 0.73 in Romania to 0.85 in Bulgaria. Considering the complexity of the question, this can be regarded as an acceptable level of inter-rater reliability (Krippendorff 2004).

In analyzing these quantitative data, we first calculated the country means of ratings given for the degree and the direction of perceived influence exercised by the nine specified institutional actors. These means were then aggregated per country and presented to 21 civil society researchers in the country concerned, who provided indepth written interpretations of these numerical results in their country contexts (Vandor et al. 2017). Finally, we aggregated the ratings for the countries within each group to give a group rating, all countries being weighted equally, and conducted ANOVA with post hoc tests to capture mean differences. The aggregated expert ratings and their interpretations by local researchers [see Vandor et al. (2017), and various subchapters, e.g., Kuti (2017) or Smilova (2017)], combined with country-specific comparative and conceptual studies of the region, formed the main body of evidence for our study.
The online survey also contained an exploratory open question concerned with ongoing and future trends in CS in the various countries. Respondents were asked to identify and describe the developments they were expecting in their own country over the next $10-15$ years. ${ }^{6}$ The purpose of this question was to induce participants to reflect on institutional context factors and their likely influence on CS. Such future-oriented framings motivate the analysis of deep structures and underlying problems rather than surface-level information (Klayman and Schoemaker 1993). Respondents were thus invited not only to describe their knowledge about the current institutional context (e.g., of current challenges), but also to organize this knowledge for predictive purposes.

After eliminating incomplete answers, we ended up with 496 descriptions of expected developments contributed by 179 different experts. These texts were content-analyzed by two independent raters, in two rounds. In the first, each description was coded inductively (Mayring 2010; Stemler 2001). Comparison and discussion of their coding led to 55 different categories. Examples are:

- social entrepreneurship (typical quote: "The past 15 years have seen a proliferation of new CSOs [...]. This is likely to continue. Given the plethora of trainings on financial sustainability.")

\footnotetext{
${ }^{6}$ Full question: "What is your best guess: Which will be the major trends in civil society over the next $10-15$ years? What will be the implications of these trends for the civil society itself? [...]. You can refer to specific trends in civil society (e.g., changing influence of government on civil society, change in private donations) or general trends in society that will have strong implications for civil society (e.g., demographic change and its implications for care-giving)."
} 
- increased government control (typical quote: "It can be expected that government will be making much greater pressure on civil society at least in Bosnia and Herzegovina to be able to control it, both through laws and establishing GONGOs.")

In the second round, we selected those categories referring directly to our nine institutional actors, of which there were 22 (e.g., for the actor government, decreasing public funding: for the actor church, increasing influence of the church: see also Table 4). The results of this qualitative content analysis were used to provide quotes illustrative of the perceived influence of individual actors.

\section{Findings: The Role of Civil Societies' Institutional Context in CEE}

Our data, both qualitative and quantitative, reveal considerable differences between the country groups as regards the perceived influence on civil society of the various institutional actors, the roles of domestic government and foreign institutions being seen as particularly decisive. After reporting on these inter-group differences, we will take a closer look at the role of the institutional context in each of the three country groups in turn.

\section{Differences in Civil Societies' Institutional Context}

Across all countries, domestic government and foreign institutions were consistently identified as the most influential institutional actors in shaping civil society (for a summary of our quantitative data, including ANOVA post hoc test results, see Table 3). Our experts gave their highest ratings on the 6-point scale to central government ( mean $=4.61, \mathrm{SD}=1.37)$, the European Union $($ mean $=$ 4.31, $\mathrm{SD}=1.30)$, and foreign donors $($ mean $=4.25$; $\mathrm{SD}=1.32$ ). At the other end of the spectrum, corporations (mean $=2.82, \quad \mathrm{SD}=1.27)$ and private philanthropists (mean $=2.79, \mathrm{SD}=1.31$ ) were perceived as least influential on civil societies in the region.

Nevertheless, there are substantial inter-group differences with regard to the mean ratings awarded to domestic government and foreign actors. In the Visegrád countries and Slovenia (Group 1), domestic institutional actors are perceived as most influential. This is not surprising, given that these countries, despite some recent setbacks and with the exception of Hungary, are regarded as largely consolidated democracies (Freedom House 2018). Most foreign donor institutions, which were often Western organizations, withdrew from these countries during the process of EU accession formally completed in May 2004. As membership of the EU implies that European funds are managed and distributed by local authorities, these have increased in relative importance. In the countries of the Western Balkans (Group 3), by contrast, foreign actors are seen as most influential. As these countries are at a rather early stage in the accession process, they are striving to adapt to the EU's legal frameworks in order to meet its requirements. Furthermore, some of the Western Balkan countries are still considered post-conflict states, which implies a continuing strong presence of foreign organizations aimed at conflict resolution and peace-keeping. Finally, the data for Bulgaria, Croatia and Romania, the countries forming Group 2 , present a mixed picture. Both foreign and domestic institutional forces are considered as influential, hinting at a transitional stage. The legacy of the EU accession process is still visible in the institutional context, but domestic institutions are slowly emerging as significant players.

Our qualitative data substantiate and enrich these findings on the differences regarding CSOs' institutional context (see Table 4). While some of the expected trends described in them are common to all country groups (e.g., increase in private donations, more collaboration with companies), many others are not (e.g., rise in governmental illiberalism, increase in donor dependence). This is additional evidence that the three groups differ in the makeup of their institutional contexts. It also provides illustrations that allow us to better understand experts' perception of actors' influence as positive or negative, as well as impulses for deeper analysis in the following subsections.

\section{Government-Dominated Context in the Visegrád Countries and Slovenia}

In this first group of countries, the influence of the EU is perceived as moderate, comparable to the influence of local and regional governments, while most other institutional actors are assessed as having a moderate to low level of influence (see Fig. 1). In all cases, the most influential institutional player is the respective central government. This may be because central governments not only provide essential funding for CSOs, but also create the legal framework in which they operate and influence the political and public environment (Fink-Hafner and Novak 2017; Kuti 2017; Szabó and Márkus 2014). However, the direction of their influence is assessed divergently. In the Czech Republic, Poland and Slovenia no clear picture emerges, whereas the majority of Hungarian and Slovakian experts regard it negatively. Taking into account recent developments in the Visegrád countries and Slovenia, these perceptions may even have worsened since we collected our data. In particular, two factors may serve as explanations: the increasing control exerted over CSOs by increasingly authoritarian or "illiberal" governments and the resulting 
Table 3 Perceived influence of institutional actors (degree and direction) by country groups

\begin{tabular}{|c|c|c|c|c|c|c|c|}
\hline & \multicolumn{4}{|c|}{ Group means } & \multicolumn{3}{|c|}{ Post hoc means comparison (Tukey test 1 ) } \\
\hline & $\begin{array}{l}\text { All } 14 \\
\text { countries }\end{array}$ & $\begin{array}{l}\text { Group } 1 \\
(\mathrm{CZ}, \mathrm{HU}, \mathrm{PL}, \\
\text { SK, SI) }\end{array}$ & $\begin{array}{l}\text { Group } 2 \\
\text { (BG, } \\
\mathrm{HR}, \mathrm{RO})\end{array}$ & $\begin{array}{l}\text { Group } 3 \\
\text { (AL, BiH, NMK, } \\
\text { MNE, SRB, XK) }\end{array}$ & $\begin{array}{l}\Delta(\text { Group 1- } \\
\text { Group 2) }\end{array}$ & $\begin{array}{l}\Delta(\text { Group 1- } \\
\text { Group 3) }\end{array}$ & $\begin{array}{l}\Delta(\text { Group } 2- \\
\text { Group 3) }\end{array}$ \\
\hline $\begin{array}{l}\text { Perceived influence of } \\
\text { central government }\end{array}$ & 4.61 & 4.97 & 4.45 & 4.38 & $p<0.05$ & $p<0.01$ & n.s. \\
\hline Direction of influence & -0.25 & -0.31 & -0.06 & -0.30 & $p<0.05$ & n.s. & $p<0.05$ \\
\hline $\begin{array}{l}\text { Perceived influence of } \\
\text { regional government }\end{array}$ & 3.32 & 3.48 & 3.14 & 3.31 & n.s. & n.s. & n.s. \\
\hline Direction of influence & -0.04 & 0.03 & -0.09 & -0.07 & n.s. & n.s. & n.s. \\
\hline $\begin{array}{l}\text { Perceived influence of } \\
\text { municipal government }\end{array}$ & 3.80 & 3.93 & 3.97 & 3.59 & n.s. ${ }^{a}$ & n.s. ${ }^{a}$ & n.s. ${ }^{\mathrm{a}}$ \\
\hline Direction of influence & 0.03 & 0.16 & -0.03 & -0.04 & n.s. ${ }^{a}$ & $p<0.05^{\mathrm{a}}$ & n.s. ${ }^{a}$ \\
\hline $\begin{array}{l}\text { Influence of the European } \\
\text { Union }\end{array}$ & 4.31 & 3.66 & 4.42 & 4.83 & $p<0.001^{\mathrm{a}}$ & $p<0.001^{\mathrm{a}}$ & n.s. ${ }^{a}$ \\
\hline Direction of influence & 0.54 & 0.48 & 0.63 & 0.55 & n.s. ${ }^{a}$ & n.s. ${ }^{a}$ & n.s. ${ }^{a}$ \\
\hline $\begin{array}{l}\text { Perceived influence of } \\
\text { foreign donors }\end{array}$ & 4.25 & 3.46 & 4.42 & 4.86 & $p<0.001^{\mathrm{a}}$ & $p<0.001^{\mathrm{a}}$ & $p<0.05^{\mathrm{a}}$ \\
\hline Direction of influence & 0.67 & 0.75 & 0.68 & 0.58 & n.s. ${ }^{\mathrm{a}}$ & $p<0.05^{\mathrm{a}}$ & n.s. ${ }^{a}$ \\
\hline $\begin{array}{l}\text { Perceived influence of } \\
\text { corporations }\end{array}$ & 2.82 & 3.04 & 2.98 & 2.52 & n.s. ${ }^{a}$ & $p<0.01^{\mathrm{a}}$ & $p<0.05^{\mathrm{a}}$ \\
\hline Direction of influence & 0.13 & 0.24 & 0.19 & -0.05 & n.s. & $p<0.01$ & n.s. ${ }^{a}$ \\
\hline $\begin{array}{l}\text { Perceived influence of } \\
\text { media }\end{array}$ & 4.01 & 3.75 & 4.26 & 4.09 & $p<0.05^{\mathrm{a}}$ & n.s. ${ }^{a}$ & n.s. ${ }^{a}$ \\
\hline Direction of influence & 0.03 & 0.09 & 0.00 & -0.01 & n.s. ${ }^{a}$ & n.s. ${ }^{a}$ & n.s. ${ }^{a}$ \\
\hline $\begin{array}{l}\text { Perceived influence of } \\
\text { private philanthropists }\end{array}$ & 2.79 & 2.76 & 2.95 & 2.71 & n.s. & n.s. & n.s. \\
\hline Direction of influence & 0.59 & 0.72 & 0.64 & 0.42 & n.s. & $p<0.001$ & $p<0.05$ \\
\hline $\begin{array}{l}\text { Perceived influence of } \\
\text { religious institutions }\end{array}$ & 3.09 & 3.43 & 3.21 & 2.70 & $p<0.05^{\mathrm{a}}$ & $p<0.001^{\mathrm{a}}$ & n.s. ${ }^{a}$ \\
\hline Direction of influence & -0.03 & 0.18 & -0.13 & -0.18 & $p<0.05^{\mathrm{a}}$ & $p<0.001^{\mathrm{a}}$ & n.s. ${ }^{a}$ \\
\hline
\end{tabular}

${ }^{\mathrm{a}}$ Games-Howell test result reported instead of Tukey test result to account for inhomogeneity of sample variances

Level of significance: $* * * p<0.01 ; * * p<0.05 ; * p<0.1$

polarization of (civil) society (Ekiert et al. 2017b). Given the recent political developments in the countries of Group 1 , the experts surveyed suggest that these trends are likely to continue.

As Greskovits (2015) has noted, the influence of parties and government on CSOs in this group of countries has greatly increased. Particularly in Hungary, and more recently in Poland, such interventions have reduced the independence of CSOs and their ability to criticize public authorities, which in turn has been fueling public distrust of civil society. Generally, a hostile attitude toward CSOs can be observed, leading to incidents such as the blockade of European Economic Area (EEA) grants in Hungary, or the termination of state funding for women's CSOs in Poland. One Hungarian respondent notes "continuing efforts by a corrupt regime to dominate and control all forms of social opposition, including [...] civil society organizations." 7

At the same time, governments have established organizations to pursue their political agendas, thus deliberately furthering the process of polarization of (civil) society along ideological lines. Although, up to now, this development has mostly affected organizations active in the fields of advocacy and policy work, the general trend is much broader. Furthermore, polarization is likely to spread into other parts of society, causing tensions and reducing public trust in CS (Ekiert et al. 2017a). According to one Polish respondent, "polarization will reflect the general division in Polish political culture between a nationalist-

\footnotetext{
$\overline{7}$ All statements in this section were provided in the qualitative part of the survey.
} 
Table 4 Expected developments (institutional actor-related categories): relative frequency per country group

\begin{tabular}{|c|c|c|c|}
\hline \multirow[t]{2}{*}{ Categories } & \multicolumn{3}{|c|}{ Percentage of experts per country group } \\
\hline & $\begin{array}{l}\text { Group } 1(\mathrm{CZ}, \mathrm{HU}, \mathrm{PL}, \mathrm{SK} \\
\mathrm{SI})(\%)\end{array}$ & $\begin{array}{l}\text { Group } 2(\mathrm{BG}, \mathrm{HR}, \\
\mathrm{RO})(\%)\end{array}$ & $\begin{array}{l}\text { Group } 3(\mathrm{AL}, \mathrm{BiH}, \mathrm{NMK}, \mathrm{MNE} \text {, } \\
\text { SRB, XK) }(\%)\end{array}$ \\
\hline European Union: increase in EU funding & 5.3 & 13.9 & 7.5 \\
\hline European Union: decrease in EU funding & 5.3 & 11.1 & 1.5 \\
\hline $\begin{array}{l}\text { European Union: general positive influence of } \\
\text { EU integration }\end{array}$ & 5.3 & 11.1 & 19.4 \\
\hline European Union: bureaucratization & 1.3 & 11.1 & 1.5 \\
\hline Foreign donors: withdrawal of foreign donors & 2.6 & 5.6 & 22.4 \\
\hline $\begin{array}{l}\text { Foreign donors: decrease in funds provided by } \\
\text { foreign donors }\end{array}$ & 5.3 & 8.3 & 19.4 \\
\hline $\begin{array}{l}\text { Foreign donors: increase in funds provided by } \\
\text { foreign donors }\end{array}$ & 1.3 & 2.8 & 0.0 \\
\hline Foreign donors: donor-driven agenda setting & 0.0 & 0.0 & 10.4 \\
\hline Foreign donors: donor dependence & 2.6 & 2.8 & 13.4 \\
\hline $\begin{array}{l}\text { Government: increased government control of } \\
\text { CSOs }\end{array}$ & 21.1 & 11.1 & 14.9 \\
\hline Government: decrease in influence on CSOs & 3.9 & 5.6 & 4.5 \\
\hline Government: decrease of public funding & 14.5 & 2.8 & 7.5 \\
\hline Government: increase in public funding & 0.0 & 5.6 & 4.5 \\
\hline Government: corruption & 7.9 & 2.8 & 9.0 \\
\hline Government: increasingly illiberalism & 17.1 & 0.0 & 4.5 \\
\hline $\begin{array}{l}\text { Government: more collaboration with civil } \\
\text { society }\end{array}$ & 7.9 & 8.3 & 9.0 \\
\hline Church: decreased influence & 1.3 & 2.8 & 0.0 \\
\hline Church: increased influence & 2.6 & 5.6 & 0.0 \\
\hline $\begin{array}{l}\text { Corporations: more collaboration with civil } \\
\text { society }\end{array}$ & 9.2 & 13.9 & 9.0 \\
\hline Corporations: more private donations & 20.0 & 13.9 & 7.5 \\
\hline $\begin{array}{l}\text { Individual donors: more individual private } \\
\text { donations }\end{array}$ & 15.8 & 13.9 & 13.4 \\
\hline
\end{tabular}

Number of respondents by country group: Group 1, 76; Group 2, 36; Group 3, 67

religious-populist orientation and a liberal-cosmopolitan, pro-European one." This trend is not restricted to the frequently cited examples of Poland and Hungary. As one Slovenian respondent notes: "Far right groups are founding small NGOs, calling themselves civil society. They are louder than any other democratic groups."

While the process of joining the EU is widely considered a success story in this group (Fink-Hafner and Novak 2017; Freyburg and Richter 2010; Grabbe 2006), the EU's perceived positive influence on the institutional context has declined since accession in 2004. Attitudes toward the EU's influence are also rather ambivalent, surprisingly perhaps because, despite the declining political leverage of EU institutions, European funding continues to be crucial for many CSOs post-accession (Brusis 2010). However, the allocation of funds is often firmly in the hands of local authorities (Fink-Hafner and Novak 2017; Kuti 2017;
Szabó and Márkus 2014), a fact also reflected in experts' ratings of municipal governments, which they assessed much more positively than central or regional governments across all five countries. What is more, the bureaucratic requirements for acquiring $\mathrm{EU}$ funding requires levels of organizational capacity beyond many smaller, communitybased CSOs (Brusis 2010; Kutter and Trappmann 2010; Strečanský 2017), as one Hungarian survey respondent remarks: "Only the biggest NGOs are able to engage in international activities directly financed by the European Commission without government influence."

Likewise, international aid agencies and foreign donors reduced their spending after EU accession. Now, though they are sometimes the only significant source of funding for advocacy work, especially that related to sensitive topics such as lesbian, gay, bisexual, transgender, and queer (LGBTQ) rights, their influence is shrinking. This 
Fig. 1 Perceived influence of institutional forces in government-dominated contexts (CZ, HU, PL, SI and SK)

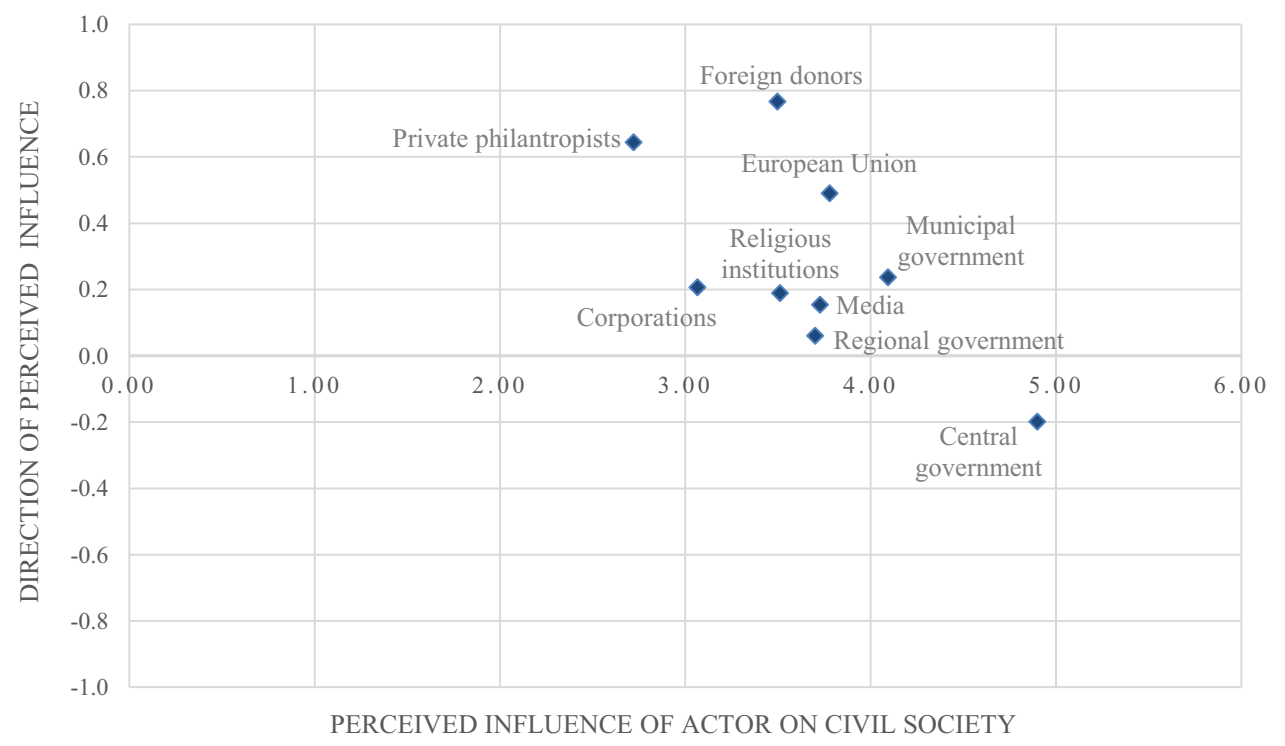

too is reflected in the expert ratings, which assess foreign aid as more positive, but less influential than those for the other country groups. In the case of Hungary, foreign donor institutions have been further challenged by central government attempts to seize control over funding decisions (Kuti 2017).

Given increasingly restricted access to government funds and the decline in foreign funding, two tendencies that are expected to continue, many CSOs face major challenges. This feeling is articulated explicitly by one Hungarian respondent: "CSO funding will change significantly. Currently, most Hungarian CSOs are operating with money received from the government, the EU and foreign foundations. Since [such flows] have decreased and changed in the past couple of years, the CSO sector needs to adapt and turn toward individual [sources of] funds and corporate sponsorships, which are scarce at the moment." It is hoped that private philanthropy will be boosted by the percentage-tax rule, a provision in force in Poland, Hungary, and Slovakia that allows citizens to donate $1-2 \%$ of their income tax to eligible charitable organizations. It was intended not only to substitute for the withdrawal of foreign donor funds, but also to provide a funding source independent of government decisions (Strečanský and Török 2016; Török 2016).

Overall, the institutional context for civil societies in the Czech Republic, Hungary, Poland, Slovakia, and Slovenia has been undergoing fundamental changes over the last few years, especially as regards the role of central governments in CS and their attitudes toward it. After a period of Europeanization and stabilization, CSOs are now operating in contexts in which central governments are increasingly becoming the "center of gravity" (again). This change has coincided with increasingly hostile attitudes toward, and limited funding for CSOs that self-identify, or are labeled as "liberal." The result has been to create expectations of further political change, with uncertain prospects for CS, among the experts surveyed.

\section{Mixed Institutional Context in Bulgaria, Croatia and Romania}

The picture provided by our data for Group 2, made up of countries who joined the EU between 2007 and 2013, is less clear. As can be seen in Fig. 2, central governments and the EU, which remains an important source of funding, are evaluated as equally influential. However, while central governments' influence on CS is assessed negatively, that of the EU is seen as positive. Moreover, the perceived influence of foreign donors, which are also important sources of funding, is rather similar to that of the EU, in terms of both degree and direction (unlike in Group 1), although it is expected to decline from the present high level. In all three countries, experts report some degree of crowding out of non-EU foreign donors, around and after accession, which has presented new challenges for CSOs. On the other hand, the dedicated work of CSOs and civic activists in these countries is valued as a driver toward EU accession, which has contributed to the creation of a favorable legal framework for CSOs (Bežovan et al. 2017; Parau 2009; Smilova 2017).

As regards EU funding, some important changes can be observed. First, in these formerly rather centralized countries, distribution of EU funds is often the responsibility of local authorities that were established mainly for this purpose following accession (Brusis 2010; Bruszt 2008). Accordingly, municipalities are perceived as influential actors and funders shaping the legal and financial 
Fig. 2 Perceived influence of institutional forces in mixed contexts (BG, HR, and RO)

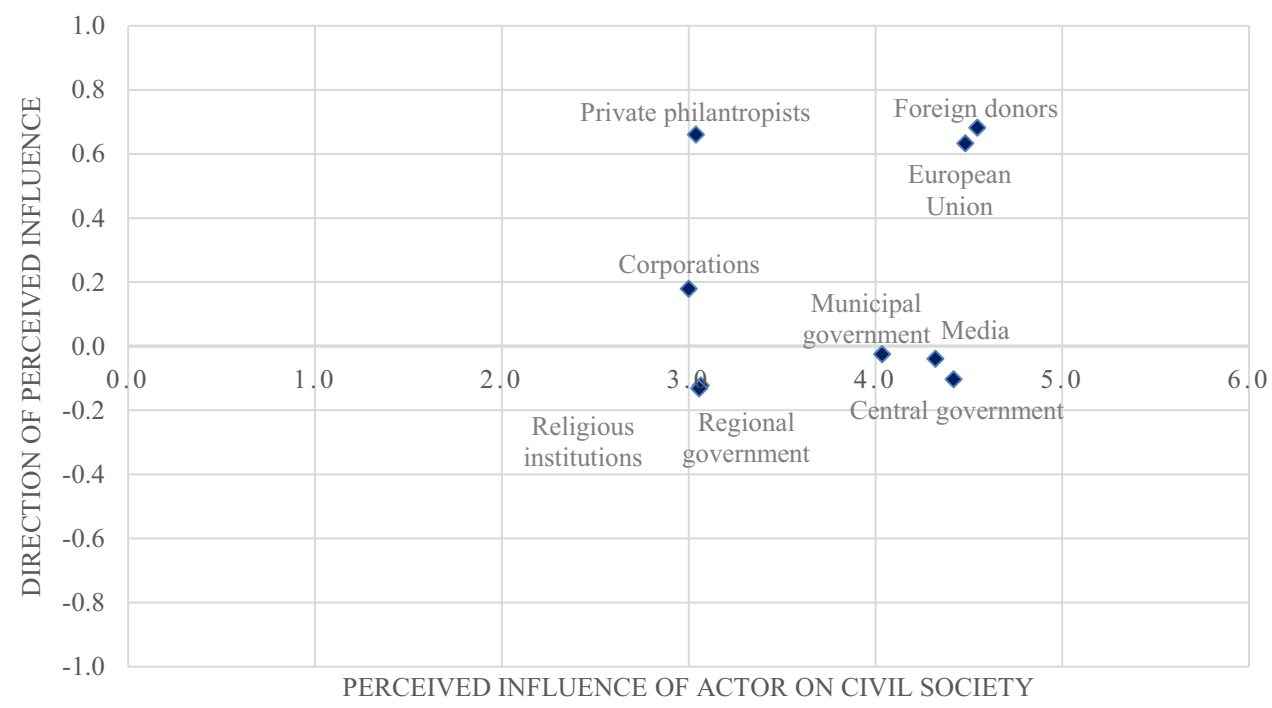

environment of CSOs (see also Fig. 2). Even so, their overall direction of influence is assessed as rather neutral because of their propensity to corruption in some countries (e.g., Bulgaria, see Smilova 2017). Second, there is widespread uncertainty about the future of EU funding for CS. Some experts fear a decrease, whereas others hope for increasing and reliable support. Third, to obtain EU funding CSOs require considerable administrative capabilities, which they still have to build up, or else must come together in alliances. As one Bulgarian respondent puts it: "CSOs are now forming alliances to get big EU projects. This trend began in the mid-2000s, as relevant EU funding was too big for most individual CSOs to handle." Furthermore, public administrations often lack the ability to access and administer such funds. In the words of a Croatian respondent, "calls for EU funds managed by the central government' ministries and agencies are announced extremely late. The government doesn't have enough capacity [...]. All this creates financial insecurity and often even leads to the insolvency of CSOs." This outlook presents new challenges, especially for advocacy CSOs (Heideman 2018) and organizations concerned with minority rights, which have traditionally been funded by Western donor organizations (Nimu 2018).

By comparison with the two other country groups, the media are perceived as highly influential in Group 2. However, there are intra-group differences. Whereas in Romania their influence is considered to be modest, but overall positive, it is seen as strong and negative in Bulgaria. There, press freedom indices have decreased significantly in recent years. Many newspapers and broadcasters are owned by relatives of an influential politician who has been associated with organized crime and who is believed to exert control over media content (Smilova 2017). The Bulgarian media's image has been further damaged by a campaign they launched against CSOs critical of the government and their most visible leaders (which itself aggravated CSOs negative public image) (Smilova 2017). A Bulgarian respondent states: "As a result of a targeted smearing media campaign against CSOs (especially those funded by foreign donors), there is a growing distrust in CSOs. An often voiced criticism against activist CSOs is that they lack legitimacy-they are not representative."

To sum up, the institutional context for CS in Bulgaria, Croatia and Romania remains challenging and uncertain. Despite the influence of the EU on policymaking and CS policies, the heritage of a rather paternalistic state is visible in each of these countries, for instance in poor state-CSO relations and high levels of bureaucracy and overregulation (Bežovan et al. 2017).

\section{Foreign Actor-Dominated Context in the Western Balkans}

In the countries of Group 3, central governments are perceived as less influential than the EU and foreign donor institutions. As can be seen in Fig. 3, governments' influence is assessed to be just as strong and negative in absolute terms as in Group 1. However, foreign institutional forces seem to constitute an important counterweight.

That may be because none of the Western Balkan countries has yet joined the EU, although all wish to do. Furthermore, with the exception of Albania, they are all are successor states of the former Socialist Republic of Yugoslavia, and all of them were involved in the civil wars and ethnic conflicts that followed the dissolution of Yugoslavia in the 1990s. Therefore, the institutional context of these comparatively young states is shaped by 
Fig. 3 Perceived influence of institutional forces in foreign actor-dominated contexts (AL, $\mathrm{BiH}, \mathrm{NMK}, \mathrm{MNE}, \mathrm{SRB}$, and $\mathrm{XK}$ )

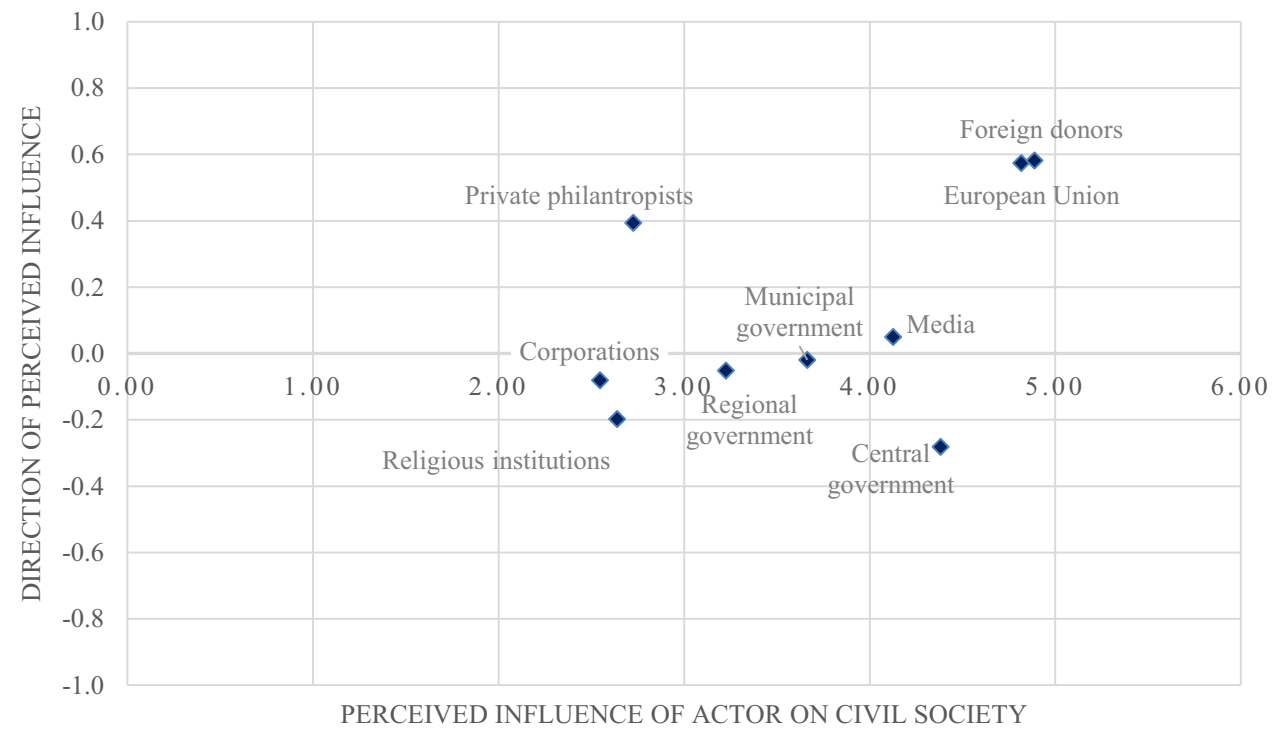

ongoing nation-building, ethnic tensions, and sometimes still fragile conflict resolution processes. Most of the countries are classified as "hybrid regimes" by Freedom House's Nations in Transit Report (Freedom House 2018), which supports the assessment that central governments are often "part of the problem" (TACSO 2014, pp. 30-31). Their power is, however, assessed as less pronounced than in Group 1.

By contrast, the EU is considered to be the most influential institutional actor. Furthermore, its influence is widely perceived as positive, an assessment which can be attributed to at least three factors. First, the EU is seen as a source of hope and a trigger for the liberalization and Europeanization of CS. Second, the accession process demands that states adapt their legal frameworks to EU requirements, which also benefits CS in general and CSOs in particular. For instance, governments must introduce participation rules to ensure (TACSO 2014) the involvement of non-state actors in policy formulation and implementation (Kutter and Trappmann 2010), as one Albanian respondent points out: "In recent years, government agencies have increasingly engaged CSOs in the drafting of sub-laws, strategies and action plans, and in the joint implementation of projects. In the future, it is expected that the government will increase incentives for the process of dialogue with CSOs." Third, the EU is also an important source of funding as there are low levels of access to individual donations or public spending. Like many other international organizations, it channels much of its aid through CSOs (Fagan 2011).

Similar arguments can be made for foreign donor institutions, whose influence is perceived to be almost as great as the EU's and also as largely positive by the surveyed experts. However, many such institutions are now slowly withdrawing or are expected to do so in the coming years (Vandor et al. 2017). Accordingly, their influence is expected to decline. Our experts raised concerns about likely replacement funding sources: "In a country of transition, when foreign donors are leaving state institutions, private organizations and private donors should jump in. This is not happening in Serbia and I believe the CSOs will change their goals to accommodate political elites" (Serbian respondent).

Despite the positive picture painted by our respondents, foreign funding has also been subject to criticism in postcrisis countries. Foreign donors' activities are accused of altering or ignoring existing CS structures and of promoting "NGO-ization." By this is meant the development of Western-style project-oriented CSOs capable of meeting the demands of foreign donors but not necessarily embedded in the local community (Aksartova 2009; Jacobsson and Saxonberg 2013; Mercer 2002). Consequently, there has been criticism that such organizations fail to engage with communities and local issues, and are in general not overly sustainable. Moreover, EU funds are often accessible only for a few professional CSOs which lack local embeddedness (Fagan 2011; Pallas 2016) or are very close to the government. As one North Macedonian respondent remarks, the "EU is the biggest potential donor in the Western Balkans, but their support for CS is project based, not institutional. In countries which are EUcandidates, some of the EU funds are funneled through government bodies with a clear political bias toward funding GONGOs [government-operated nongovernmental organizations], not the genuine civil society organizations." These problems of donor dependency and lack of financial sustainability are evident in the Western Balkans. Domestic private philanthropists and corporations are 
still relatively unimportant and unlikely to fill the gap left by the expected withdrawal of foreign donors, posing a potential threat to the sustainability of many CSOs (Appe and Pallas 2018).

Similarly, the overall political climate is challenging due to high levels of corruption and media bias. None of the Group 3 countries is considered to have a "free press" according to standard indices such as those of Reporters Without Borders and Freedom House. The causes lie in ownership structures, journalistic self-censorship to avoid harassment and violence, and the lack of funding for alternative media. Consequently, the media are often unable to fulfill their watchdog function. Governmentfriendly media outlets have even launched campaigns against CSOs and their leaders, defaming them as "foreign spies." One Montenegrin respondent notes that "the government uses the media under its influence $[\ldots]$ to destroy the reputation of those CSOs and their leaders who criticize the work of the government." Consequently, media influence is perceived as rather strong and clearly negative (see Fig. 3).

Generally, CSOs in the Western Balkans face many challenges caused by the withdrawal of funding from foreign institutional actors that have played a major role in shaping their contexts. For some countries, EU membership is still out of reach for various reasons including the ongoing tensions in the region and the continuing refusal of some states to acknowledge Kosovo's independence. The reverberations of past crises can still be felt, and whether CS will achieve stability is yet to be seen.

\section{Conclusions}

This study of 14 countries is the first to explore the role of institutional forces in shaping CS in CEE. Building on historical institutionalism, we have directed our attention toward the role of both domestic and foreign institutional forces, and identified patterns common to groups of countries. In doing so, we first defined three such groups based on the stage they have reached in the process of EU accession since this has been and remains a juncture of critical historical importance for CS's development in CEE. Survey data from experts in the various countries corroborated this grouping and provided us with detailed descriptions of the different institutional contexts of CS in the three groups and the resultant challenges for CS in each of them.

In the first group (Czech Republic, Hungary, Poland, Slovakia, and Slovenia), domestic actors-central, regional and municipal governments-are perceived as the most influential institutional actors, but there is no consensus on the direction of their influence. In particular, the influence of central governments draws criticism from many of the experts surveyed. In contrast, the institutional environments of Group 3 countries (Albania, Bosnia and Herzegovina, Kosovo, North Macedonia, Montenegro and Serbia) are seen as mainly shaped by foreign forces, in particular foreign donor organizations and the EU. The second group (Bulgaria, Croatia and Romania) occupies an intermediate position, with both domestic governments and foreign institutions perceived as exercising a high degree of influence.

These findings provide empirical evidence in favor of using historical institutionalism as a theoretical lens. The composition of our groups was based on historical developments, specifically the process of EU accession, and our respondents' assessments on the degree and direction of institutional actors' influence strongly supports this clustering. Our analysis particularly highlights the substantial but changing role of the EU: from a strong source of hope and a highly important funder for CS in the pre-accession stage, to an important external authority and supporter of civil rights and liberties in those countries that acceded between 2007 and 2013, to a rather marginalized institution that is losing power under the challenge of increasingly authoritarian national governments in the longer-standing EU members. Our findings also show a parallel decline in the impact of foreign donor organizations. While these remain active in the Western Balkans, they largely terminated their financial support for CS in the second and third clusters of countries in the early 2000s and late 1990s, respectively. At the same time, our results reinforce and expand on earlier findings that foreign donors have somewhat ambivalent effects on CS.

Furthermore, our findings underscore the influence of institutional environments on CS itself. In an environment dominated by foreign actors such as that in countries belonging to our Group 3 (and to some extent Group 2), these may provide powerful support to CS as facilitators of policy dialogue and funders. At the same time, though, their influence can lead to the perception of CS as a cultural "import" lacking local embeddedness and legitimacy (Fink-Hafner and Novak 2017; Spahić-Šiljak 2017). Moreover, the power exercised by foreign actors leads to high levels of dependency, creating massive challenges for CSOs as soon as donors reduce or terminate their commitment. At the other end of the spectrum, the institutional environment in Group 1 is characterized by strong domestic public authorities which have moved into fill the space left by diminishing foreign influence and legitimacy. In this group, CSOs had earlier developed considerable size and importance but now find themselves in a defensive position. In Hungary and Poland in particular, CSOs are increasingly faced not just with a reduction in access to public funds but with open hostility from governments and 
the media; Hungarian CSOs have even been denounced as "mercenaries" 8 working for foreign foundations. It remains to be seen whether, as our respondents hope, such developments can be counteracted by an increase in private philanthropy and the establishment of new, locally rooted and community-based organizations.

Finally, while previous research often treats CS in CEE as fairly homogenous, our findings clearly confirm the argument of Foa and Ekiert (2017) that there is generally no such thing as a typical "post-communist civil society." We found groups of countries which have taken similar paths but also high levels of inter-group divergence. This suggests the need for a more finely grained framework for international comparisons of CS than that provided by social origins theory. Subsuming all countries of CEE under the rubric "an interesting mix of 'statist' and 'socialdemocratic' tendencies" (Salamon and Anheier 1998, p. 20) does not sufficiently consider the rich variety of institutional frameworks. As our findings show, rather than the level of domestic public expenditure on social welfare, foreign institutional actors including the EU, have played a key role in determining the development of CS in the region. Thus, we need new analytical frameworks that go beyond intrasocietal issues to take into account the globalized nature of societies, and therefore foreign institutions.

Certainly, our study has its limitations. First, the selection of respondents to the survey was based on a snowball sampling approach (Coleman 1958). As a result, in spite of the use of multiple starting points for sampling, we acknowledge that our selection may be biased toward individuals with connections to academia and private philanthropists. Next, though our survey data supports the assumptions that the prospect of EU membership has a strong, positive influence on CS, while accession itself leaves CS dependent on national governments, these ideas require further corroboration by a more detailed institutional analysis. Finally, our measure of the influence of institutional actors is rather general, being restricted to its degree and direction as perceived by experts, and perhaps insufficiently differentiated given the rich variety of CS across the 14 countries.

In sum, and despite these limitations, our study contributes to the literature by using a comparative analysis to draw a much needed overall picture of the current state of civil societies in CEE. The clustering we suggested has proven useful in analyzing the differences and similarities between the regions' CSs. Moreover, our findings promote understanding of how context shapes the trajectories of CS, while underscoring the claim that researching the influence of institutional contexts can provide valuable insights into

\footnotetext{
$\overline{8}$ http://www.euronews.com/2018/04/12/alarm-in-hungary-over-inti midatory-list-of-soros-mercenaries.
}

the development of CS in and beyond CEE. An analysis of institutional environments can provide indications, and possibly a few warning signs, as to the possible future paths of CS in countries that have recently joined the EU or are currently seeking entry. These insights could also be transferred to other settings where powerful foreign actors, such as foundations or multinational corporations, form part of CSOs' institutional context. Last but not least, we hope that our research will encourage more fine-grained comparative analyses of CS that, ideally, investigate the role of institutional actors longitudinally.

Acknowledgements Open access funding provided by Vienna University of Economics and Business (WU).

Funding The data collection for this study was funded in parts by ERSTE Foundation.

\section{Compliance with Ethical Standards}

Conflict of interest The authors declare that they have no conflict of interest.

Open Access This article is distributed under the terms of the Creative Commons Attribution 4.0 International License (http://crea tivecommons.org/licenses/by/4.0/), which permits unrestricted use, distribution, and reproduction in any medium, provided you give appropriate credit to the original author(s) and the source, provide a link to the Creative Commons license, and indicate if changes were made.

\section{References}

Aksartova, S. (2009). Promoting civil society or diffusing NGOs? In D. Hammack \& S. Heydemann (Eds.), Globalization, philanthropy, and civil society: Projecting institutional logics abroad (pp. 160-191). Bloomington: Indiana University Press.

Appe, S., \& Pallas, C. L. (2018). Aid reduction and local civil society: Causes, comparisons, and consequences. VOLUNTAS: International Journal of Voluntary and Nonprofit Organizations, 29(2), $245-255$.

Baranowski, M., \& Gross, D. A. (2006). Influence over state agency activities: A test of two survey-based measures. State Politics and Policy Quarterly, 6(2), 220-238.

Beichelt, T., Hahn, I., Schimmelfennig, F., \& Worschech, S. (Eds.). (2014). Civil society and democracy promotion. Basingstoke: Palgrave Macmillan.

Bežovan, G., Matančević, J., \& Baturina, D. (2017). Country Report: Croatia. In P. Vandor, N. Traxler, R. Millner, \& M. Meyer (Eds.), Civil Society in Central and Eastern Europe: Challenges and opportunities (pp. 111-125). Vienna: ERSTE Foundation.

Biernacki, P., \& Waldorf, D. (1981). Snowball sampling: Problems and techniques of chain referral sampling. Sociological Methods and Research, 10(2), 141-163.

Bogner, A., Litting, B., \& Menz, W. (2009). Expert interviews-An introduction to a new methological debate. In A. Bogner, B. Litting, \& W. Menz (Eds.), Interviewing experts (pp. 252-273). London: Palgrave Macmillan.

Bogner, A., \& Menz, W. (2009). The theory-generating expert interview: Epistemological interest, forms of knowledge, 
interaction. In A. Bogner, B. Litting, \& W. Menz (Eds.), Interviewing experts (pp. 43-80). London: Palgrave Macmillan.

Boli, J., \& Thomas, G. M. (1997). World culture in the world polity: A century of international non-governmental organization. American Sociological Review, 62(2), 171-190.

Börzel, T. A. (2010). Why you don't always get what you want: EU enlargement and civil society in Central and Eastern Europe. Acta Politica, 45(1-2), 1-10.

Börzel, T. A., \& Buzogány, A. (2010). Governing EU accession in transition countries. The role of non-state actors. Acta Politica, 45(1-2), 158-182.

Börzel, T. A., \& Risse, T. (2005). Public-private partnerships: Effective and legitimate tools of international governance (pp. 195-216). Ontario: University of Toronto Press Toronto.

Brusis, M. (2010). European incentives and regional interest representation in Central and Eastern European countries. Acta Politica, 45(1/2), 70-89.

Bruszt, L. (2008). Multi-level governance-The Eastern versions: Emerging patterns of regional developmental governance in the new member states. Regional and Federal Studies, 18(5), $607-627$.

Buzogány, A. (2011). Stairway to heaven or highway to hell? Anbivalent Europeanization and Civil Society in Central and Eastern Europe. In H. Kouki \& E. Romanos (Eds.), Protest beyond borders. Contentious politics in Europe since 1945 (pp. 69-85). New York: Berghahn Books.

Coleman, J. (1958). Relational analysis: The study of social organizations with survey methods. Human Organization, 17, $28-36$.

Dimitrova, A., \& Buzogány, A. (2014). Post-accession policy-making in Bulgaria and Romania: Can non-state actors use EU rules to promote better governance? Journal of Common Market Studies, 52(1), 139-156.

Domaradzka, A. (2018). Urban social movements and the right to the city: An introduction to the special issue on urban mobilization. VOLUNTAS International Journal of Voluntary and Nonprofit Organizations, 29(4), 607-620.

Drori, G. S., Meyer, J. W., \& Hwang, H. (Eds.). (2006). Globalization and organization: World society and organizational change. Oxford: Oxford University Press.

Dür, A. (2008). Measuring interest group influence in the EU: A note on methodology. European Union Politics, 9(4), 559-576.

Ekiert, G., \& Foa, R. (2011). Civil society weakness in postcommunist Europe: A preliminary assessment. Carlo Alberto Notebooks, 198, 1-45.

Ekiert, G., \& Kubik, J. (2014). Myths and realities of civil society. Journal of Democracy, 25(1), 46-58.

Ekiert, G., Kubik, J., \& Wenzel, M. (2017a). Country Report: Poland. In P. Vandor, N. Traxler, R. Millner, \& M. Meyer (Eds.), Civil society in central and Eastern Europe: Challenges and opportunities (pp. 76-91). Vienna: ERSTE Foundation.

Ekiert, G., Kubik, J., \& Wenzel, M. (2017b). Civil society and three dimensions of inequality in post-1989 Poland. Comparative Politics, 49(3), 331-350.

Esping-Andersen, G. (1990). The three worlds of welfare capitalism. Princeton, NJ: Princeton University Press.

European Commission. (2016). European enlargement policy. Check current status. https://ec.europa.eu/neighbourhood-enlargement/ countries/check-current-status_en. Retrieved 05 February 2019.

Fagan, A. (2006). Transnational aid for civil society development in post-socialist Europe: Democratic consolidation or a new imperialism? The Journal of Communist Studies and Transition Politics, 22(1), 115-134.

Fagan, A. (2011). EU assistance for civil society in Kosovo: A step too far for democracy promotion? Democratization, 18(3), 707-730.
Fagan, A., \& Wunsch, N. (2018). Fostering institutionalisation? The impact of the EU accession process on state-civil society relations in Serbia. Acta Politica, 45, 1-18.

Fink-Hafner, D., \& Novak, M. (2017). Country Report: Slovenia. In P. Vandor, N. Traxler, R. Millner, \& M. Meyer (Eds.), Civil Society in Central and Eastern Europe: Challenges and opportunities (pp. 126-142). Vienna: ERSTE Foundation.

Foa, R. S., \& Ekiert, G. (2017). The weakness of postcommunist civil society reassessed. European Journal of Political Research, $56(2), 419-439$.

Freedom House. (2018). Confronting illiberalism. Nations in transit 2018. Retrieved from https://freedomhouse.org/sites/default/ files/FH_NationsInTransit_Web_PDF_FINAL_2018_03_16.pdf.

Freyburg, T., \& Richter, S. (2010). National identity matters: The limited impact of EU political conditionality in the Western Balkans. Journal of European Public Policy, 17(2), 263-281.

Ganev, V. I. (2013). Post-accession hooliganism. Democratic governance in Bulgaria and Romania after 2007. East European Politics and Societies, 27(1), 26-44.

Grabbe, H. (2006). The EU's transformative power. Europeanization through conditionality in Central and Eastern Europe. Basingstoke: Palgrave Macmillan.

Greskovits, B. (2015). The hollowing and backsliding of democracy in East Central Europe. Global Policy, 6, 28-37.

Heideman, L. J. (2018). Making civil society sustainable: The legacy of USAID in croatia. VOLUNTAS: International Journal of Voluntary and Nonprofit Organizations, 29(2), 333-347.

Heinrich, V. F. (2005). Studying civil society across the world: Exploring the Thorny issues of conceptualization and measurement. Journal of Civil Society, 1(3), 211-228.

Heinrich, V. F. (Ed.). (2007). CIVICUS global survey of the state of civil society, volume 1: Country profiles (Vol. 1). Bloomfield: Kumarian Press.

Howard, M. M. (2002). The weakness of postcommunist civil society. Journal of Democracy, 13(1), 157-169.

Howard, M. M. (2003). The weakness of civil society in postcommunist Europe. Cambridge: Cambridge University Press.

Jacobsson, K., \& Saxonberg, S. (2013). Beyond NGO-ization: The development of social movements in Central and Eastern Europe. London: Routledge.

Jezierska, K., \& Polanska, D. V. (2018). Social movements seen as radical political actors: The case of the Polish Tenants' movement. VOLUNTAS: International Journal of Voluntary and Nonprofit Organizations, 29(4), 683-696.

Kabalo, P. (2013). A fifth nonprofit regime? Revisiting social origins theory using Jewish associational life as a new state model. Nonprofit and Voluntary Sector Quarterly, 38(4), 627-642.

Kamerāde, D., Crotty, J., \& Ljubownikow, S. (2016). Civil liberties and volunteering in six former Soviet Union countries. Nonprofit and Voluntary Sector Quarterly, 45(6), 1150-1168.

Kendall, J., Anheier, H., \& Potucek, M. (2000). Editorial: Ten years after: The third sector and civil society in Central and Eastern Europe. VOLUNTAS: International Journal of Voluntary and Nonprofit Organizations, 11(2), 103-106.

Kerlin, J. A. (2013). Defining social enterprise across different contexts: A conceptual framework based on institutional factors. Nonprofit and Voluntary Sector Quarterly, 42(1), 84-108.

Kitschelt, H. (1992). Political regime change: Structure and processdriven explanations?. New York: JSTOR.

Klayman, J., \& Schoemaker, P. J. H. (1993). Thinking about the future: A cognitive perspective. Journal of Forecasting, 12(2), $161-186$

Krippendorff, K. (2004). Reliability in content analysis: Some common misconceptions and recommendations. Human Communication Research, 30(3), 411-433. 
Kuti, É. (2017). Country Report: Hungary. In P. Vandor, N. Traxler, R. Millner, \& M. Meyer (Eds.), Civil Society in Central and Eastern Europe: Challenges and opportunities (pp. 58-75). Vienna: ERSTE Foundation.

Kutter, A., \& Trappmann, V. (2010). Civil society in Central and Eastern Europe: The ambivalent legacy of accession. Acta Politica, 45(1/2), 41-69.

Lauth, H.-J. (2017). Zivilgesellschaft und die Qualität der Demokratie. In A. Croissant, S. Kneip, \& A. Petring (Eds.), Demokratie, Diktatur, Gerechtigkeit. Wiesbaden: Springer.

March, J. G., \& Olsen, J. P. (1984). The new institutionalism: Organizational factors in political life. American Political Science Review, 78(3), 734-749.

Mayring, P. (2010). Qualitative inhaltsanalyse. In Handbuch qualitative Forschung in der Psychologie (pp. 601-613).

Mercer, C. (2002). NGOs, civil society and democratization: A critical review of the literature. Progress in Development Studies, 2(1), 5-22.

Merkel, W. (2010). Are dictatorships returning? Revisiting the 'democratic rollback'hypothesis. Contemporary Politics, 16(1), $17-31$.

Meuser, M., \& Nagel, U. (2009). The expert interview and changes in knowledge production. In A. Bogner, B. Litting, \& W. Menz (Eds.), Interviewing experts (pp. 17-42). London: Palgrave Macmillan.

Meyer, J. W., Boli, J., \& Thomas, G. M. (1987). Ontology and rationalization in the western cultural account. In G. M. Thomas, J. W. Meyer, F. O. Ramirez, \& J. Boli (Eds.), Institutional structure: Constituting state, society, and the individual (pp. 12-38). Newbury Park, CA: Sage.

Moore, B. J. (1966). Social origins of dictatorship and democracy: Lords and peasant in the making of the modern world. Boston: Beacon Press.

Navrátil, J., \& Pecjal, J. (2017). Country report: Czech Republic. In P. Vandor, N. Traxler, R. Millner, \& M. Meyer (Eds.), Civil Society in Central and Eastern Europe: Challenges and opportunities (pp. 43-57). Vienna: ERSTE Foundation.

Nimu, A. (2018). Surviving mechanisms and strategies of gender equality NGOs in Romania and Poland. VOLUNTAS International Journal of Voluntary and Nonprofit Organizations, 29(2), 310-332.

Noutcheva, G., \& Bechev, D. (2008). The successful laggards. Bulgaria and Romania's accession to the EU. East European Politics and Societies, 22(1), 114-144.

Ottaway, M., \& Carothers, T. (2000). Funding virtue: Civil society aid and democracy promotion. Washington, DC: Carnegie Endowment.

Pallas, C. L. (2016). Aid reduction and local civil society in conflictaffected states: New research and stakeholder dialogue. Journal of Peacebuilding \& Development, 11(1), 105-109.

Parau, C. E. (2009). Impaling Dracula: How EU accession empowered civil society in Romania. West European Politics, 32(1), 119-141.

Peters, B. G. (2011). Institutional theory in political science: The new institutionalism. New York: Bloomsbury Publishing.

Piotrowski, G. (2015). What are Eastern European social movements and how to study them? Intersections East European Journal of Society and Politics, 1(3), 4-15.

Pop-Eleches, G., \& Tucker, J. A. (2013). Associated with the past? Communist legacies and civic participation in post-communist countries. East European Politics and Societies, 27(1), 45-68.

Ragin, C. C. (1998). Comments on "Social origins of civil society". Voluntas, 9(3), 261-270.

Ray, L. (1999). Measuring party orientations towards European integration: Results from an expert survey. European Journal of Political Research, 36(2), 283-306.
Reljić, D., \& und Sicherheit, I. P. (2004). Who builds civil society? Civil society, mass media and democracy in post-communist countries. Geneva Centre for the Democratic Control of Armed Forces (DCAF) Working paper (131).

Rikmann, E., \& Keedus, L. (2013). Civil sectors in transformation and beyond: Preliminaries for a comparison of six Central and Eastern European Societies. VOLUNTAS: International Journal of Voluntary and Nonprofit Organizations, 24(1), 149-166.

Ruef, M., \& Scott, R. W. (1998). A multidimensional model of organizational legitimacy: Hospital survival in changing institutional environments. Administrative Science Quarterly, 43, 877-904.

Salamon, L. M., \& Anheier, H. K. (1998). Social origins of civil society: Explaining the nonprofit sector cross-nationally. Voluntas: International Journal of Voluntary and Nonprofit Organizations, 9(3), 213-248.

Salamon, L. M., Anheier, H., List, R., Toepler, S., Sokolewski, W., \& Associates. (2004). Global civil society. Dimensions of the nonprofit sector (Vol. 2). Bloomfield: Kumarian Press.

Salamon, L. M., Sokolowski, S. W., \& Anheier, H. K. (2000). Social origins of civil society: An overview. Retrieved from Baltimore. http://ccss.jhu.edu/wp-content/uploads/downloads/2011/09/ CNP_WP38_2000.pdf.

Scharpf, F. W. (1997). Games real actors play. Actor-centred institutionalism in policy research. Boulder: Westview Press.

Schimmelfennig, F., \& Sedelmeier, U. (2004). Governance by conditionality: EU rule transfer to the candidate countries of Central and Eastern Europe. Journal of European Public Policy, 11(4), 661-679.

Schmidt, V. A. (2010). Taking ideas and discourse seriously: Explaining change through discursive institutionalism as the fourth 'new institutionalism'. European Political Science Review, 2(1), 1-25.

Scott, W. R. (2000). Institutional change and healthcare organizations From professional dominance to managed care (1st ed.). Chicago, IL: University of Chicago Press.

Scott, W. R., \& Meyer, J. W. (Eds.). (1994). Institutional environments and organizations. Structural complexity and individualism. Thousand Oaks: Sage.

Sedelmeier, U. (2014). Europe after the Eastern Enlargement of the European Union: 2004-2014. Retrieved from https://eu.boell. org/en/2014/06/10/europe-after-eastern-enlargement-europeanunion-2004-2014.

Sedelmeier, U. (2017). Political safeguards against democratic backsliding in the EU. The limits of material sanctions and the scope of social pressure. Journal of European Public Policy, 24(3), 337-351.

Shapovalova, N., \& Youngs, R. (2014). The changing nature of EU support to civil society. In T. Beichelt, I. Hahn, F. Schimmelfennig, \& S. Worschech (Eds.), Civil society and democracy promotion (pp. 86-109). Basingstoke: Palgrave Macmillan.

Skocpol, T. (1973). A critical review of Barrington Moore's social origins of dictatorship and democracy. Politics and Society, 4(1), $1-34$.

Skocpol, T., \& Somers, M. (1980). The uses of comparative history in macrosocial inquiry. Comparative Studies in Society and History, 22(2), 174-197.

Smets, M., Morris, T., \& Greenwood, R. (2012). From practice to field: A multilevel model of practice-driven institutional change. Academy of Management Journal, 55(4), 877-904.

Smilova, R. (2017). Country Report: Bulgaria. In P. Vandor, N. Traxler, R. Millner, \& M. Meyer (Eds.), Civil Society in Central and Eastern Europe: Challenges and opportunities (pp. 125-143). Vienna: ERSTE Foundation.

Smith, S. R., \& Grønbjerg, K. A. (2006). Scope and theory of government-nonprofit relations. In W. W. Powell \& R. Steinberg 
(Eds.), The nonprofit sector: A research handbook (Vol. 2, pp. 221-242). London: Yale University Press.

Spahić-Šiljak, Z. (2017). Country Report: Bosnia and Herzegovina. In P. Vandor, N. Traxler, R. Millner, \& M. Meyer (Eds.), Civil Society in Central and Eastern Europe: Challenges and opportunities (pp. 188-203). Vienna: ERSTE Foundation.

Steinberg, R., \& Young, D. R. (1998). A comment on Salamon and Anheier's "Social origins of civil society". Voluntas: International Journal of Voluntary and Nonprofit Organizations, 9(3), 249-260.

Stemler, S. (2001). An overview of content analysis. Practical Assessment, Research and Evaluation, 7(17), 137-146.

Strečanský, B. (2017). Country report: Slovakia. In P. Vandor, N. Traxler, R. Millner, \& M. Meyer (Eds.), Civil Society in Central and Eastern Europe: Challenges and opportunities (pp. 92-110). Vienna: ERSTE Foundation.

Strečanský, B., \& Török, M. (Eds.). (2016). Assessment of the impact of the percentage tax designations: Past, present, future. Vienna: ERSTE Foundation and Centrum Pre Filantropiu.

Szabó, M. \& Márkus, E. (2014). Civil society in Hungary. 25 years after. In Schreier (Ed.), Civil Society in the 'Visegrád Four'Data and Literature in the Czech Republic, Hungary, Poland and Slovakia. Berlin: Maecenata Institut für Philantropie und Zivilgesellschaft,(Vol. Opusculum Nr 74) (pp. 94-129).

TACSO. (2014). Civil society organizations in Bosnia and Herzegovina: Needs Assessment Report. Technical Assistance for Civil Society Organisations.

Taylor, M. (2000). Media relations in Bosnia: A role for public relations in building civil society. Public Relations Review, 26(1), 1-14.

Thelen, K. (1999). Historical institutionalism in comparative politics. Annual Review of Political Science, 2(1), 369-404.
Tilly, C. (1984). Big structures, large processes, huge comparisons. Russell: Sage.

Titanski-Hooper, J. (2015). (B)ordering in the EU: Croatia's Path Toward Becoming 'European'. In N. Pasamitros, T. Phillips, N. Rossis, \& T. Koszadinova (Eds.), An Agenda for Western Balkans: From Elite Politics to Social Sustainability (pp. 34-43). Stuttgart: Ibidem.

Toepler, S., \& Salamon, L. M. (2003). NGO development in Central and Eastern Europe: An empirical overview. East European Quarterly, 37(3), 365-378.

Tolbert, P. S. (1985). Institutional environments and resource dependence: Sources of administrative structure in institutions of higher education. Administrative Science Quarterly, 30(1), $1-13$.

Török, M. (2016). Policy making. In B. T. M. Strečanský (Ed.), Assessment of the impact of the percentage tax designations: Past, present, future. Vienna: ERSTE Foundation and Centrum Pre Filantropiu.

USAID. (2018). The 2017 CSO sustainability index for central and Eastern Europe and Eurasia. Retrieved from: https://www.usaid. gov/sites/default/files/documents/1866/CSOSI_EE_2017_Regio nal_Report_FINAL_2.pdf.

Vandor, P., Traxler, N., Millner, R., \& Meyer, M. (2017). Civil society in Central and Eastern Europe: Challenges and opportunities. Vienna: Erste Stiftung.

Wunsch, N. (2016). Coming full circle? Differential empowerment in Croatia's EU accession process. Journal of European Public Policy, 23(8), 1199-1217.

Publisher's Note Springer Nature remains neutral with regard to jurisdictional claims in published maps and institutional affiliations. 